\title{
Uji parameter spesifik dan nonspesifik simplisia daun senggani (Melastoma malabathricum L.)
}

\author{
Rini Digna Evifania ${ }^{1, *}$, Pratiwi Apridamayanti ${ }^{1}$, Rafika Sari ${ }^{1}$ \\ ${ }^{I}$ Program Studi Farmasi, Fakultas Kedokteran Universitas Tanjungpura, Kalimantan Barat, Indonesia \\ * Korespondensi: rinidigna16@student.untan.ac.id
}

\begin{abstract}
Abstrak
Latar belakang: Simplisia daun senggani adalah bahan alami yang berupa berupa serbuk kering daun senggani. Simplisia perlu dilakukan uji untuk menjamin mutu dan keamanan bagi konsumen, serta menjaga keseragaman khasiatnya. Penelitian ini bertujuan untuk mengetahui kualitas serbuk hasil simplisia daun senggani (Melastoma malabathricum L.) dari Pontianak, Kalimantan Barat. Metode: Uji simplisia daun senggani dilakukan dengan melihat parameter spesifik dan nonspesifik simplisia. Hasil: Hasil uji parameter spesifik yaitu uji organoleptis menunjukkan bentuk simplisia daun senggani adalah butiran kasar, berwarna coklat kehijauan, dengan rasa kelat, serta memiliki aroma yang aromatis kuat. Uji parameter nonspesifik didapatkan kadar abu total adalah sebesar 6,369\% dan kadar abu tidak larut asam adalah 3,543\%. Kesimpulan: Uji organoleptis dan uji kadar abu simplisia memenuhi syarat, tetapi hasil uji kadar abu tidak larut asam tidak memenuhi syarat.
\end{abstract}

Kata kunci: simplisia, daun senggani (Melastoma malabathricum L), parameter spesifik, parameter nonspesifik

\section{Specific and nonspecific parameter test of simplicia of senggani (Melastoma malabathricum L.) leaves}

\begin{abstract}
Background: Simplicia of senggani leave is a natural ingredient in the form of dry powder. Simplicia needs to be tested to ensure the quality and safety for consumption as well as to maintain uniformity of its properties. The research aimed to assess the quality of simplicia of senggani (Melastoma malabathricum L.) obtained from Pontianak, West Kalimantan. Methods: Simplicia test was done by observing specific and nonspecific parameters of the simplicia. Results: Specific parameter test (organoleptic test) showed coarse-grained simplicia with greenish-brown color, rough, and had a strong aromatic odor. Nonspecific parameter tests showed total ash content was $6.369 \%$ and the acid-insoluble ash content was 3,543\%. Conclusions. Organoleptic test and ash-content test meet the standard while acid-insoluble ash does not meet the standard.
\end{abstract}

Keywords: simplicia, senggani leave (Melastoma malabathricum L), specific parameters, nonspecific parameters

\section{Pendahuluan}

Senggani merupakan jenis gulma yang mudah ditemukan di berbagai tempat. Tumbuhan senggani adalah pohon kecil dengan batang berkayu berwarna coklat, tingginya 1-,5m, memiliki cabang simpodial. Daun senggani tunggaldengan tangkai yang letaknya berhadapan saling menyilang. Daun berwarna hijau berbantuk bulat telur sepanjang 2-20 cm , lebar 1-8 $\mathrm{cm}$, ujung dan pangkal daun meruncing, tepi daun rata, permukaan kasar dengan rambut pendek jarang-jarang dan kaku memiliki tiga tulang daun berbentuk lengkung dengan panjang petiolus 512 $\mathrm{mm}^{2}$

Penelitian yang dilakukan oleh Laia dkk (2019) menunjukkan bawa daun senggani mengandung flavonoid, saponin, alkaloid, tanin, dan polifenol. ${ }^{3}$ Daun senggani mengandung asam ursolik, asam 2-hidroksiursolik, $\beta$-sitosterol-3-O-D-glukopiranosid, gliserol, gliko lipid, 1,2-dilinolenil-3-O-Dgalaktopiranosid, rhamnogalakturonan, homo galakturonan, polisakarida, polifenol, 3,4- 
dehidroprolin amida, mefloquin, 2-(3,5Difenilpirazol-IyI) benzotiazol, kaemferol 3-O- (2',6'-di-O-transp-kumaril)- $\beta$-D-glukopiranosid, kuersetin, asam sinamat dan asam para-hidroksisinamat. Bunga senggani mengandung kaemferol, kaemferol 3-O-L-ramnopiranosid, kaemferol 3-O-Dglukopiranosid, kaemferol 3-OD-galaktopiranosid, asam ellagik dan kuarsetin. Buah senggani mengandung antosianin yang terdiri dari sianidin diheksosida, sianidin heksosida dan definidin heksosida. khasiat daun senggani adalah sebagai antidiabetes, antihiperglikemik, antioksidan, sebagai hepatoproktetif, antikoagulan, antiulser, antibakterial, penyembuh luka, gastroprotektif, peningkat fertilitas, anti kanker, antiinflamasi dan antiobesitas. Khasiat bunga dan buah senggani adalah sebagai antioksidan dan antibakterial. ${ }^{4-6}$

Simplisia menurut farmakope Indonesia merupakan bahan baku obat alami yang sudah dikeringkan dan diserbukan. ${ }^{7}$ Simplisia ada 3 jenis. Simplisia nabati merupakan simplisia dari bagian utuh atau bagian tertentu tumbuhan maupun eksudat tanaman. Simplisia hewani adalah simplisia bisa berupa hewan utuh atau zat-zat berguna dari hewan yang belum diubah menjadi bahan kimia murni misalnya, minyak ikan dan madu. Simplisia pelican dan mineral adalah simplisia berupa bahan pelican atau mineral yang diolah dengan sederhana yang belum berupa bahan kimia murni contohnya, serbuk seng dan serbuk tembaga. ${ }^{8}$ Standarisasi simplisia dilakukan untuk menjaga stabilitas dan keamanan serta mempertahankan kosistensi kandungan senyawa aktif dalam simplisia. ${ }^{8}$ Uji organoleptis dapat memberikan gambaran kerusakan produk dan kemunduran kualitas bahan misalnya akibat proses pembusukan. Kadar abu adalah zat anorganik sisa pembakakaran suatu bahan. Kadar abu merupakan jumlah mineral yang dalam suatu bahan, meliputi kebersihan dan kemurnian bahan yang dihasilkan. Uji kadar abu dilakukan untuk mengetahui besarnya mineral dalam suatu bahan atau pangan. ${ }^{8}$ Pada penelitian ini akan dilakukan standarisasi simplisia daun senggani untuk mengetahui kualitas simplisia daun senggani, untuk menjamin mutu dan keamanan kandungan simplisia daun senggani sehingga simplisia daun senggani ini aman dikomsumsi dan memiliki khasiat bagi kesehatan, baik untuk digunakan secara langsung misalnya dikomsumsi dalam bentuk seduhan teh, maupun untuk pengembangan bentuk sediaan lainnya.

\section{Metode}

Alat yang digunakan adalah blender, oven, pisau, toples kaca, wadah plastik. Bahan yang digunakan adalah sampel daun senggani yang diambil dari jalan Parit Haji Husin 2, Komplek Permata Paris, Kecamatan Pontianak selatan, kota Pontianak, Kalimantan barat.

Tanaman gaharu dan senggani dibersihkan, dipisahkan antara daun dan ranting, lalu dicuci dengan air mengalir. Daun diangin-anginkan di dalam ruangan hingga kering atau bisa juga dijemur dengan ditutup kain hitam di bawah sinar matahari. Sampel daun senggani dikeringkan dengan oven pada suhu $50^{\circ} \mathrm{C}$. Daun senggani diblender untuk dijadikan serbuk kasar simplisia, diayak menggunakan ayakan mesh 20, disimpan pada wadah kaca bertutup. ${ }^{9}$

\section{Standarisasi Simplisia}

Parameter spesifik

Uji organoleptis; serbuk simplisia diambil sedikit, dilakukan uji organoleptis yaitu bau, rasa dan warna. $^{9}$

Parameter nonspesifik

Uji kadar abu total; ditimbang krus porselin yang telah dipijarkan, dimasukan $2 \mathrm{~g}$, diratakan. Simplisia dipijarkan sehingga arang habis lalu didinginkan dalam desikator dan ditimbang. ${ }^{9}$

Uji kadar abu tidak larut asam; abu hasil penetapan kadar abu dilarutkan dalam $10 \mathrm{ml}$ asam klorida $\mathrm{P}$ selama 5 menit. Abu yang tidak larut dalam asam disaring dengan kertas saring, dicuci dengan air panas, dipijarkan hingga bobot konstan, ditimbang. ${ }^{9}$

\section{Hasil}

Metode parameter spesifik dan nonspesifik menunjukkan hasil seperti pada Tabel 1.

Tabel 1. Parameter spesifik dan nonspesifik simplisia daun senggani

\begin{tabular}{ll}
\hline \multicolumn{1}{c}{ Uji } & \multicolumn{1}{c}{ Hasil } \\
\hline Organoleptis & Bentuk : butiran kasar \\
& Warna : coklat kehijauan \\
& Rasa : kelat \\
& Bau : aromatis \\
Kadar abu & $6,369 \%$ \\
Kadar abu tidak larut & $3,543 \%$ \\
asam &
\end{tabular}




\section{Pembahasan}

Zat yang terkandung dalam simplisia mempengaruhi mutu simplisia. Standarisasi simplisia dilakukan dengan tujuan untuk meyetarakan mutu simplisia. Faktor lingkungan, iklim, ketinggian, kualitas bibit, teknologi budidaya, umur tanaman, cara pengolahan, cara pengepakan dan penyimpanan simplisia berpengaruh pada kualitas dan mutu simplisia. Waktu panen tanaman sebaiknya dilakukan pada saat tanaman masih mengandung zat aktif tinggi. ${ }^{10}$ Simplisia daun senggani dilakukan pada pagi hari karena belum banyak terjadi penguapan sehingga daun masih segar. Bagian yang diambil adalah bagian daun yang tidak terlalu tua, yaitu daun yang dekat dengan pucuk sekitar 5-8 ke bawah pucuk. Daun hasil panen langsung dipisahkan dari ranting, bunga dan buah senggani. Daun dicuci dengan air bersih yang mengalir sebanyak 2-3 kali kemudian ditiriskan dalam keranjang serta dianginkan. Pengeringan dilakukan untuk mengawetkan daun, mempertahankan mutu dan mengurangi kadar air. Pengeringan bahan bisa dengan penjemuran langsung dimana bahan ditutup dengan kain hitam atau dengan menggunakan oven. ${ }^{11}$ Daun senggani dikeringkan dengan menggunakan oven bersuhu $50^{\circ} \mathrm{C}$ selama 4-5 jam yaitu, sampai daun benar-benar kering, yaitu saat diremas akan berbunyi. Daun kering tadi kemudian diblender dan ayak menggunakan ayakan mesh 40 untuk mendapatkan ukuran simplisia yang kompak. Simplisia daun senggani yang dihasilkan sebanyak 175,8 g dari 560 $\mathrm{g}$ daun segar senggani. Simplisia daun senggani kemudian diujikan parameter spesifik dan parameter nin spesifiknya. Parameter uji spesifik dan nonspesifik ini diujikan berdasarkan pedoman dari buku materia medika Indonesia yaitu mencakup syarat untuk menjamin mutu suatu simplisia yang baik secara umum. Parameter spesifik yang digunakan adalah uji organoleptis yang mencakup bentuk, rasa, aroma, dan warna dari simplisia tersebut. Parameter uji organoleptis ini tergantung pada masing-masing tanaman. Suatu simplisia yang baik memiliki aroma, rasa, bentuk dan warna yang tidak serupa dengan tanaman asalnya, sehinggan dapat dipastikan secara organoleptis simplisia yang dihasilkan merupakan simplisia tanaman yang dimakdut. ${ }^{13}$ Simplisia senggani memiliki bentuk seperti butiran kasar dengan warna coklat kehjauan, berbau aromatis kuat dengan rasa kelat. Simplisia daun senggani kemudian disimpan didalam toples kaca bertutup rapat, dan diletakan ditempat yang kering.

Standarisasi simplisia dilakukan untuk menjaga stabilitas dan keamanan serta mempertahankan kosistensi kandungan senyawa aktif dalam simplisia. ${ }^{8}$ Uji kadar abu dan kadar abu tidak larut asam dilakukan dengan mengirim sampel ke laboratorium Politeknik negeri Pontianak jurusan teknologi pertanian, uji kadar abu dilakukan untuk melihat kandungan mineral internal dan eksternal sebagai pengaruh proses penggolahan dari awal hingga terbentuknya simplisia. Semakin tinggi kadar abu menyatakan kadar mineral bahan yang semakin tinggi. ${ }^{8}$ Prosedur uji kadar abu yang dilakukan yaitu sesuai prosedur berdasarkan buku materia medika Indonesia, didapatkan kadar abu daun senggani sebesar 6,369\%. Kadar abu total yang baik menurut standar yang tercantum dalam buku material medika Indonesia adalah tidak lebih dari $8 \%$, maka kadar abu simplisia daun senggani memenuhi standar. ${ }^{8}$ uji kadar abu menunjukan kandungan mineral dan kemurnian bahan. Abu adalah campuran bahan anorganik serta mineral dalam bahan pangan, saat dibakar bahan organic akan habis terbakar tetapi bahan anorganiknya tidak (disebut kadar abu). mineral dalam suatu bahan bisa bisa berupa garam garam organic (asam mallat, oksalat, asetat, pektat) dan garam anorganik (garam fosfat, karbonat, klorida, sulfat dan nitrat). ${ }^{8}$

Kadar abu tidak larut dalam simplisia daun senggani dilakukan dengan berdasarkan panduan buku material medika Indonesia. kadar abu tidak larut asam daun senggani adalah 3,543\%. Standar kadar abu tidak larut asam menurut standar yang tercantum dalam buku Materia Medika Indonesia adalah tidak lebih dari 1\%, maka dapat disimpulkan bahwa kadar abu tidak larut asam simplisia daun senggani tidak memenuhi standar. ${ }^{13}$ Semakin tinggi kadar abu tidak larut asam menunjukan adanya kandungan mineral baik organik/anorganik, serta kandungan silikat yang berasal dari tanah atau pasir, bahkan unsur logam perak, timbal maupun merkuri akibat kontaminan lingkungan sekitar yang diperlukan uji lebih lanjut untuk mengetahuinya. ${ }^{12}$

\section{Kesimpulan}

Hasil uji simplisia daun senggani (Melastoma 
malabathricum L.) memenuhi syarat parameter spesifik yaitu berbentuk butiran kasar, berwarna coklat kehijauan, rasa kelat dengan aroma yang aromatis kuat. Uji parameter nonspesifik didapatkan kadar abu total sebesar $6,369 \%$ dinyatakan memenuhi syarat, tetapi uji kadar abu tidak larut diperoleh sebesar $3.543 \%$ yang dinyatakan tidak memenuhi syarat.

\section{Daftar Pustaka}

1. ITIS (Integrated taxonomic information system);2017. Disitasi 29 September 2019. Tersedia dari https://www.itis.gov/servlet/SingleRpt/ingleRpt?searc $\mathrm{h}$ topic $=$ TSN\&search val ue $=965278 \#$ null.

2. Wegner W L, Herbst D R, dan Sohmer S H. Manual of the flowering plants of Hawai'i. 2 vols. Bishop museum special publication 83: University of Hawai'i anf bishop museum press, Honolulu, HI;1999.

3. Laia Y, Aulia Y, Sahara M, Masdalena S M. Uji aktivitas hepatoprotektor ekstrak etanol daun senggani (Melastoma malabathricum L) terhadap tikus (Rattus novergicus) yang diinduksi parasetamol. Biospecies. 12(2):2019;18.

4. Wong K C, Ali D M H, Boey P L. Chemical constituents and antibacterial activity of Melastoma malabathricum L.. Natural product research. 2012:26(7):609-18.

5. Khoo L T. Abas F, Abdullah J O, Tohib ER M dan Hamid M. Anticoagulant activity of polyphenolic polysaccaharides isolated from Melastoma malabathricum L. Evidence-based complementary and alternatif medicine. 2012;4(4):24-6.

6. Alwash $\mathrm{M}$ S, Ibrahim $\mathrm{N}$ dan Ahmad $\mathrm{W}$ Y. Identification and mode of action of antibacterial components from Melastoma malabathricum Linn leaves. American journal of infectious diseases. 2013;9(2):46-58.

7. Departemen Kesehatan Republik Indonesia. Farmakope edisi ke III. Jakarta: Departemen Kesehatan Republik Indonesia; 1989.

8. Maulana A. analisis parameter mutu dan kadar flavonoid pada produk teh hitam celup. \{Artikel penelitian \} Bandung: Fakultas Teknik Universitas Pasudan ; 2016.

9. Lestari R F, Suhaimi, dan Wildaniah W. Penetapan parameter standar simplisia dan ekstrak etanol daun keratom (Mitragyma speciosa Korth) yang tumbuh di kabupaten Kapuas Hulu dan kabupaten Melawi. Jurnal insan farmasi Indonesia. 2018:1(1);72-84.

10. Dalimartha S. 1001 resep herbal. Jakarta: Penebar swadaya; 2008.

11. Suranto A. Terbukti pome tumpas penyakit. Puspa swara; 2011.

12. Utami YP, Umar A H, Syahruni R dan Kadullah I. Standarisasi simplisia dan ekstrak etanol daun leilen (Clerodendrum minahassae Teisjm \& Binn). Journal of Pharmaceutical and medicinal sciences. 2(1);2017:32-9.

13. Departemen Kesehatan Republik Indonesia. Meteria medika Indonesia, jilid VI. Jakarta: Departemen Kesehatan Republik Indonesia; 1995. 